\title{
LABORATORY TESTING THE COMBINED ELONGATE STRUCTURAL ELEMENTS OF SUPPORT OF A MINE OPENING
}

\author{
${ }^{1}$ Sumy National Agrarian University, Sumy, Ukraine \\ ${ }^{2}$ Poltava University of Economics and Trade, Poltava, Ukraine
}

The stress-strain state of test specimens of the new combined structure of support of a mine opening under loads is studied. The test specimens are compound modular elements of the designed earlier combined structure of support. Every single modular element is the triangular prism, consisting of a reinforced concrete slab and a steel grid made of tube web members. The slab and web members are grouped in a complete element while concreting the slab. The tension sensor's method of experimental investigation is applied to the testing specimens. Tests of specimens are carried out under the load forced with cargoes. Loads are set in the ways that to simulate service conditions, counting the most adverse. Design features of the support and test specimens are shown. Particulars of the support and its elements, production technology, assemblies as well as the sizes are briefly described. The methodology of testing specimens, as well as the analysis of the outcomes, are presente. opening.

Keywords: testing, steel and concrete composite structure, combined structure, stress-strain state, frame, mine

\section{Introduction}

To mine working depending on their purposes as well as hydrological and geological conditions, some techniques are used. However, in all cases to mine working there is necessary to erect supports structures for prevention of fall dawn of the soil or rocks, as well as ensuring the service condition, and the design parameters and sizes of the mine openings. Presently, the profitability of supports is important. Each support has to provide reliability as well as at the same time to be simple in installation.

In recent times, notable deterioration in mining-and-geological conditions is observed, resulting in the existing supports steadily undergoes physical depreciation [1-4]. In the present instance, it should be pointed out that repairing exploited supports or erecting a new one is a labor-intensive operation and requires big material inputs [5]. For one thing, the coal mining working practice shows that the cost of renovation and maintenance in operating conditions of the supports can be as high as $10 \%$ of the value of the coal. The arch hypothesis for support designing is widespread. Even if the arches are viable structures to resist the pressure of soil may not always be possible to achieve necessary results $[6,7]$. Presently, the steel frame-arch supports are often used for mine opening [8].

\section{The analysis of literature and the problem statement}

Nevertheless, those structures have shortcomings. In the first place, it is the difficulty of ensuring the load-carrying ability of the supports of mine openings with an unstable wall rock as well as high mine pressure [9]. For mine working the anchor-frame and anchor supports are also applied [5] that have disadvantages too: requirement for the high-priced explosion-proof compressor mobile equipment; the absence of the highly efficient drilling equipment of domestically produced; labor required and complexity of anchors' installation. So, when fields are developed using mentioned above supports, these disadvantages frequently turn mine working into money-losing one because the need arises in both enormous human and monetary resources [9]. The present state of the mining sector given, the design of the new techniques and types of supports of mine opening, requiring the minimum expenses is a rather urgent challenge $[10,11]$.

The current study as research already above-mentioned focuses on the need for developing new designs of supports. In this regard, the novel structural concept of the combined structure of support to mine working is designed. It is assumed that the support will be resistant to the side pressure of soil, as well as will be less labor-consuming under construction and will contribute to decreasing the consumption of steel. The theoretical and experimental researches, including reviewing the existing supports structures of mine opening, as well as measuring their advantages and disadvantages, and studying reports of inspections, etc. are executed for the purpose achieve [5, 8, 9, 12-16]. Consequently, 
the novel system of support consisting of the combined elongate structural modular elements [17] is designed.

Initial experimental investigates [18, 19] and feasibility studies [20] show the efficiency of the designed constructive scheme. On the other hand, there are still several unstudied issues linked with designing the proposed support. Some such challenges are to study the stress-strain state of the combined elongate structural elements and measure the efficiency of the constructive concepts.

\section{Aim of the study}

That is why the purpose of the current study is to establish the regularity of developing the strains of edge fibers of specific cross-sections of test specimens depend on the load rate and also to establish a load-carrying capacity of test specimens.

\section{Methods}

To solve the delivered problem the well-established and approved experimental research method for full-scale testing specimens under the load forced by cargoes is used. The experimental method provides studying the stress-strain state of test specimens via dial indicators and tension sensors. Also, the experimental research method allows receiving strain-load relations for edge fibers of specific crosssections of test specimens.

\section{Research results and discussion}

As it is already mentioned, the structures are designed for use in the mining sector as the structures of support of the mine opening (Fig. 1a). As well, the structure can be applied for the installation of retaining walls (Fig. 1b), walls of wells (Fig. 1c), etc. The making elements of the designed structure are the combined elongate structural elements (modules). Each such module is made of a slab and web members and has a triangular prism form. The slab can be a square (this one is not considered) [19, 21] or rectangular shape (Fig. 2). Also, the slab can be reinforced concrete or steel and concrete composite.

The web members of the module (positions 3 and 4 in Figure 2) are fabricated from steel tubes, which form a spatial lattice, like "space grid structure". Normally, web members are hollow items, on the other hand, if the need arises to increase the load-carrying capacity of the module, they can be filled with concrete.

To the production of a lattice, tubes in different diameters according to GOST 10707-80 or other tube standards for the mining industry are used. The bar mesh (Figure 2 shows where bar meshes $\mathrm{C}-1$ and $\mathrm{C}-2$ are located) are fabricated from the bars at least class A400. The inserts (embedded parts) made of steel sheet (positions 1and 2 in Figure 2) serve as the connecting links between steel tube web members and a slab. The slab is reinforced with such embedded parts and the bar meshes.

a)

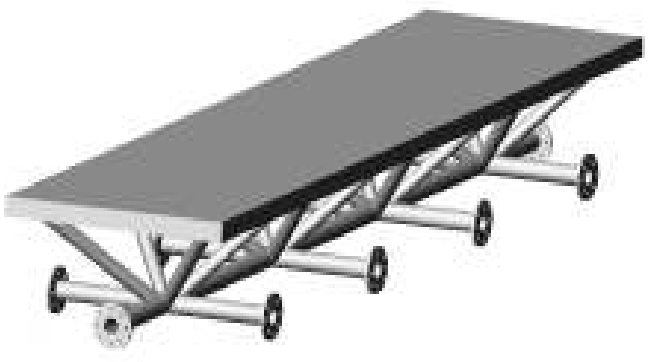

b)

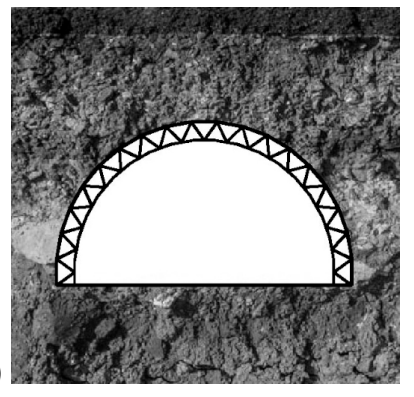

Fig. 1 - General view of combined elongate structural elements (a) and using the designed structures in the mining sector as a support of a mine opening (b).

In more detail about designed support as well as methods of production of the combined elongate structural elements can be found in the research result [22]. The geometric parameters of combined elongate structural elements and their components are defined by calculation, guided by codes of design steel, and reinforced concrete or steel and concrete composite structures [23-25]. The tilt angle of the web member lies between $30^{\circ}$ and $60^{\circ}$. It is well-known from the rules of grid structures designing.

However, in both previous [17-20, 22] and the current studies angle of $45^{\circ}$ is used. Because, such angle is known from experience designing to be the most favorable angle for grid structures, as well as to use in many similar structures [26]. 


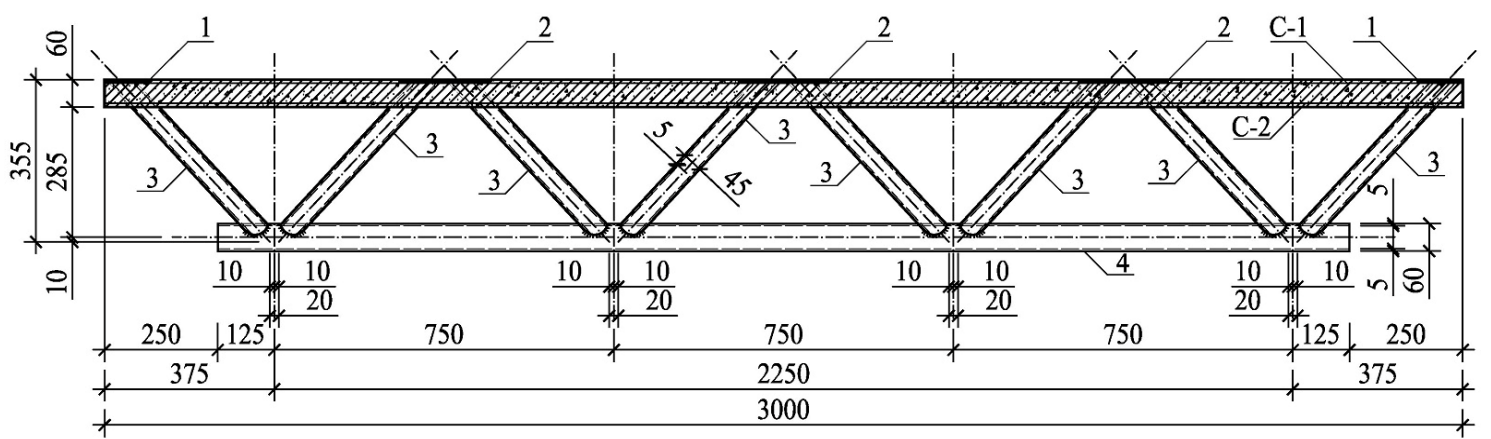

Fig. 2 - Details of the test specimen of the combined elongate structural elements (module) for mine opening: 1 and 2 - inserts from steel sheet; 3 and 4 - steel tube web members; C1, C2 - bar meshes.

The designed support is assembled from modules through connections, which can have different designs depends on the shape of the support. The combined elongate structural elements are assembled into one support, which can have as flat and as curvilinear shapes (see Fig. 1).

The amount of modules for assembling support is defined by calculation, based on the feasibility study and trial design. The method of determination of the modules amount is similar to the well-known space grid structures. This method considers such characteristics of a structure as depth and span of the module as well as the tilt angle of the web member [27].

Production of the combined elongate structural elements is carried out by monolithic or prefabricated (in this work is not considered) ways. The choice of a way depends on the size of the mine opening as well as available equipment. The features of monolithic production of modules lie in the way of concreting of elements.

Concreting carried out when the frame of the module lays turned side on the site (Fig. 3a) instead of the proper location (Fig. 3b). In this case, web members play the bearing and reinforcing roles (Fig. 4). In this way, the integrity and solidity of the module are reached.

a)

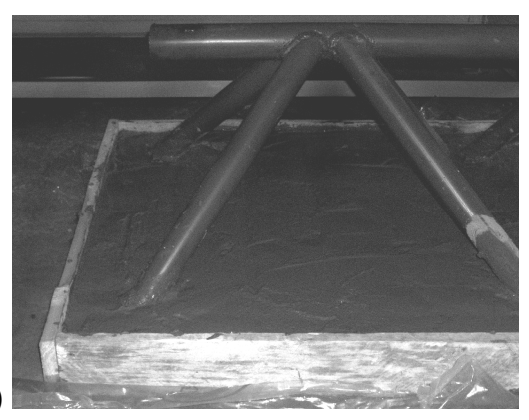

b)

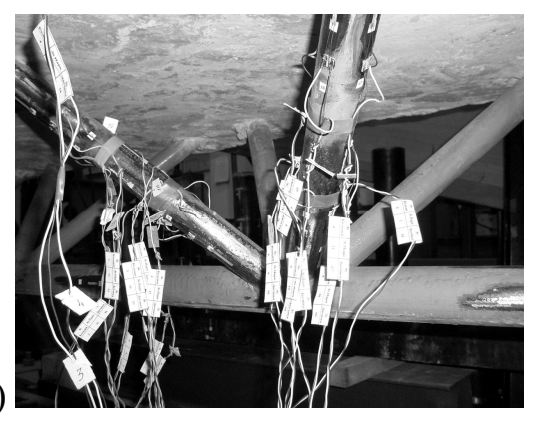

Fig. 3 - Concreting (a) and the proper location (b) of the specimen

When the prefabricated way is selected, the production of the module follows to that order: to begin with, the slab is concreted, then the web members are connected to inserts by bolts (such technique is presented in results of research [19]).

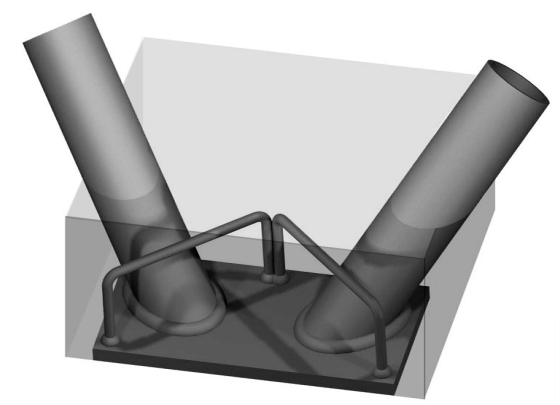

Fig. 4 - Monolithic production of the combined elongate structural elements

The application of the designed support for mine working is to achieve certain economic benefits, no matter what the way of production of the module is selected [20]. Furthermore, there is no need for a wide 
range of special racks and timbering, as is often the case during concreting in the permanent position of a structure (should not be confused with monolithic production of modules).

In greater detail, the design features about the designed support are available in the monograph [28] or guide [29].

Developing the technique of the experimental research is caused by insufficient data about of the stress-strain state of the making elements of the designed support, and their behavior under the load. The load-carrying ability of combined elongate structural elements is considered to depend on different impacts, especially on the geometrical sizes, physic-mechanical properties of materials (steel and concrete), ways of loading as well as constructive schemes, etc. Several tasks are delivered while the program of experimental researches is drawing up. The tasks are to learn the behavior and the stress-strain state of elements of the designed supports under the load; to define the load-carrying capacity of elements of the designed supports; to check whether the combined action of steel tube web members and a reinforced concrete slab is ensured; to obtain displacements of characteristic points while testing the specimen; to plot the strain-load curves, etc.

The test specimens of the combined elongate structural elements are designed and made to obtain experimental data that allows getting sufficiently assess the characteristics of the elements of the designed supports. The strains and displacements are measured in specific points of elements of the support (Fig. 5). Strains are measured via tension sensors with the multichannel measuring system VNP8 as well as dial indicators. Tension sensors are glued on web members and flank sides of the slab as Figure $3 \mathrm{~b}$ shows.

Ensuring the proper procedure of experimental researches, control samples are made of materials of the test specimens. These are concrete cubes of $150 \times 150 \times 150 \mathrm{~mm}$, strips of length $280 \mathrm{~mm}$ and $135 \mathrm{~mm}$ are cut from both steel sheets and tubes respectively and also segments of length $190 \mathrm{~mm}$ are cut off from reinforcements bar. The control samples are made to obtain the physic-mechanical properties of the used materials for making the test specimens. The control samples are tested at the same time as test specimens.

The test specimens are tested under uniform load (the load is imposed on the entire surface of a slab) as Figure 5 shows.

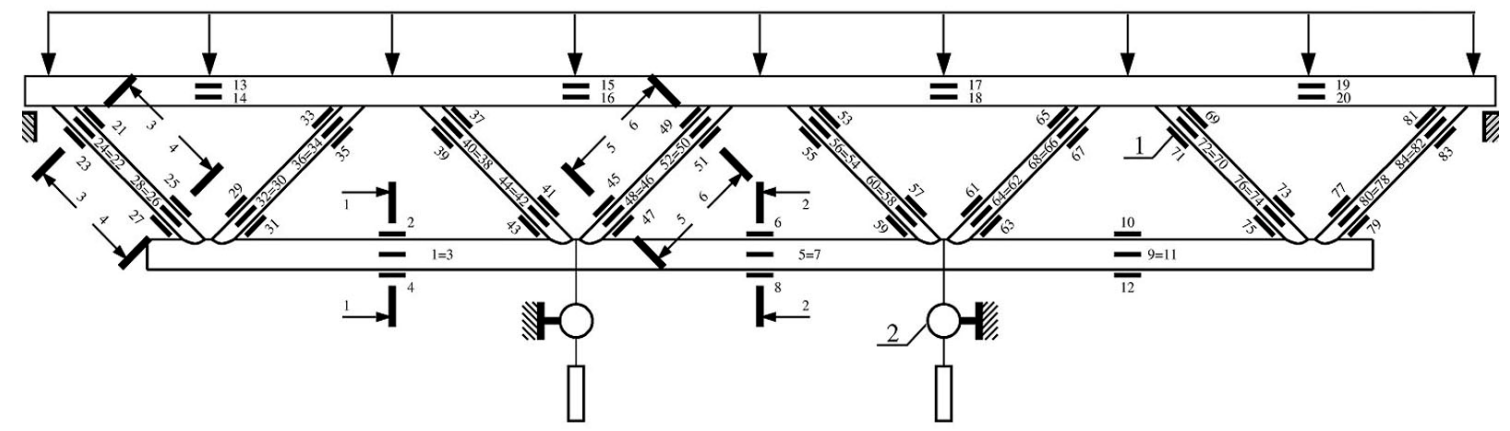

Fig. 5 - Way of loading the test specimens and the placement of tension sensors:

1 - sensors of tension; 2 - dial indicators; numbers next to sensors $1,2, \ldots, 83$ are numbers of tension sensors.

The load imitates earth pressure on supports. It should be emphasized that the test's ways of specimens imitate the worst boundary conditions that can be in the operation of the designed supports. It allows estimating a resource of load-carrying ability the designed supports objectively. Loads are imposed on the slab of the combined elongate structural element as cargoes in the form of the short solid cylinders (Fig. 6).

Arrangement of tension sensors on the surface where put the cargoes on is unreasonable because they are damaged by cargoes. Nevertheless, that arrangement of tension sensors allows measurement of strains correctly with consequent analyzing the stress-strain state of test specimens objectively and accurately. Based on the structural specifics as well as experience of experimental investigation for measurement of strains of materials are used tension sensors of certain lengths: $30 \mathrm{~mm}$ - for steel; $50 \mathrm{~mm}$ - for concrete.

Following the experimental researches program, the test specimens are not broken down. As a result of the tests, the value of the strain in the extreme filament of the cross-sections are obtained and some strain-load relations are plotted (Fig. 7). 
a)

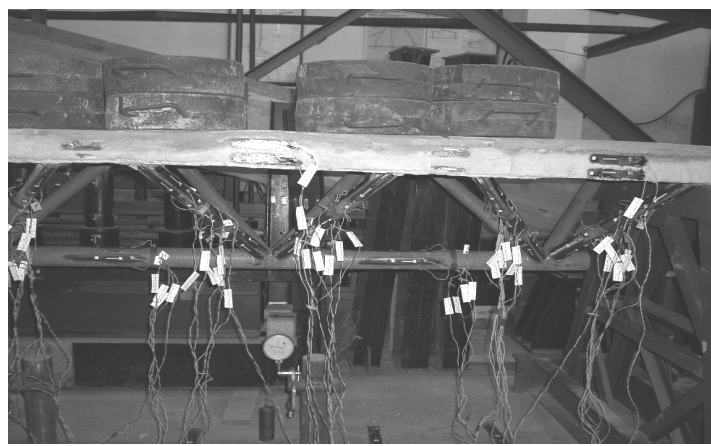

b)

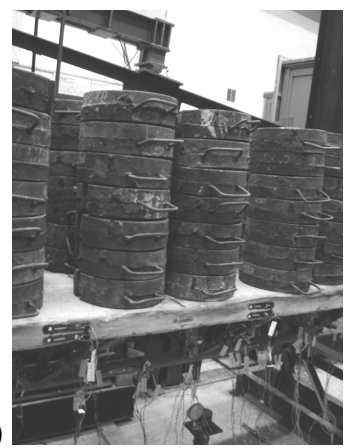

Fig. 6 - The specimen under the load while testing (a) and at the last stage of loading (b).
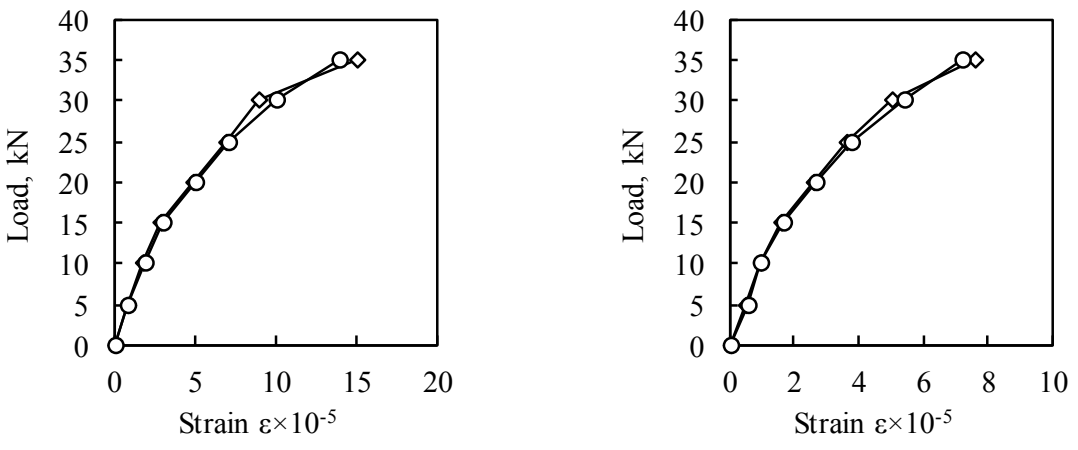

$\multimap$ sensor $17 \multimap-$ sensor 18

$\multimap$ sensor $19 \multimap-$ sensor 20

Fig. 7 - The strain-load relations in the extreme filament of the cross-sections

The analysis of the test results shows in general that combined elongate structural elements are in the elastic behavior during the test. This stress-strain state of elements under such loadings, in general, is usual and corresponds to the well-known patterns. It means that the technique (the current codes for calculation of carrying structures [23-25,29] that is used for the test specimens designing is an acceptable one. It means that at this stage of researches there is no need to develop the theory of calculation of the designed supports of mine opening. The experimental data shows the designed structures are effective under the load. It should be noted that during testing at the load that is $85 \%$ from design ultimate load still elastic work of materials is observed.

\section{Conclusion}

First of all the new support structure for the mining industry use has been created as well as studied. Experimental researches of the combined elongate structural elements of a mine opening were conducted, as a result, the delivered goal was reached, such as the new data is established that has both the scientific novelty and the practical value as well as gives awareness about specificities of structure behavior under loading, as well as both the stress-strain state and the efficiency of the structure are established. Besides, the actual strains depending on the level load in characteristic sections, and also the load-carrying ability of test specimens are obtained. Taking into account that the test specimens are tested under operational load, during the experiment the steel structural elements are deformed linearly, that is, there is a direct relationship between the strains and load.

After analyzing the results, both tensile and compressive forces are found to act in cross-sections of steel tube web members. That is common for space grid structures.

From the results, tensile forces are found to act in cross-sections 1-1 and 2-2 (see Fig. 5). As well as, strains are found to increase more on the bottom side of the tube (tension sensor 4 in cross-section 1-1, tension sensor 8 in cross-section 2-2) than on the top side.

From the results also, compressive forces are found to act in the normal section of the reinforced concrete slab. Besides, in the hight of the normal section, the strains are roughly the same, in contrast to the steel tube.

In common, it should be noted that all components (web members, reinforcement, inserts, and slab) of the combined elongate structural elements are in combined action during all the loading stages. All mentioned and other results in the previous investigation demonstrate the efficiency of the structural concept of the combined elongate structural elements for the mining industry use. 


\section{REFERENCES}

1. Barla G., Barla M. Innovative tunnelling construction methods in squeezing rock // What future for the infrastructure, Pàtron Editore Bologna, 2008, pp. 103-119.

2. Kaiser P.K., Cai M. Design of rock support system under rockburst condition // Journal of Rock Mechanics and Geotechnical Engineering, 2012, 4(3), pp. 215-227.

3. Uyar G.G., Aksoy C.O. New support suggestions to high swelling clayey rock mass // Journal of Mining Science, 2018, 54(4), pp. 617-627. https://doi.org/10.1134/S1062739118044087

4. Wang M., Zheng D., Niu S., Li W. Large deformation of tunnels in longwall coal mines // Environmental earth sciences, 2019, 78(2), 45. https://doi.org/10.1007/s12665-019-8044-3

5. Bulat A.F. Advanced technologies for tunnel supporting in Ukrainian coal mines // Visnyk of the National Academy of Sciences of Ukraine, 2014, (1), pp. 74-79. https://doi.org/10.15407/visn2014.01.074

6. Elrawy W.R., Abdelhaffez G.S., Saleem H.A. Stability assessment of underground openings using different rock support systems // Rudarsko-geološko-naftni zbornik, 2020, 35(1), pp. 49-64.

7. Gharavi M., Shafiezadeh N. A Comparison of underground opening support design methods in jointed rock mass // International Journal of Engineering, Transactions B: Applications, 2008, 21 (3), pp. 235-248.

8. Storchak G.G, Korol A.Yu, Gapieiev S.M. The issue of increasing the stability of discontinuous workings with metal support under the conditions of irregular loading // Up-to-date resource- and energy-saving technologies in mining industry, 2013, 11(1), pp. 143-152.

9. Khalimendik O.V, Storchak G.G, Khalimendik O.V, Pustoviy V.V. Ways of maintenance prolonged sustainability of long mine workings in conditions unbalanced loads when using metal support spaceframe // Up-to-date resource- and energysaving technologies in mining industry, 2013, 12(2), pp. 157-165.

10. Lu Y., Ke W., Huang X., Xiao M., Huang J., Chen J. Comparative analysis of different construction methods for mine tunnels // In IOP Conference Series: Materials Science and Engineering, 2019, 780(4), 042032. https://doi.org/10.1088/1757$899 \mathrm{X} / 780 / 4 / 042032$

11. Stables B., Mirabile B. An improved load measuring device for underground mining standing supports // In Proceedings of the 38th International Conference on Ground Control in Mining, 2019, p. 364. Society for Mining, Metallurgy \& Exploration.

12. Aksenov V.V., Kazantsev A.A., Dortman A.A. Obzor suschestvuyuschih tipov krepi gornyih vyrabotok i analiz ih vozmozhnosti primeneniya $\mathrm{v}$ geovinchesternoy tehnologii // Gornyiy informatsionno-analiticheskiy byulleten (nauchnotehnicheskiy zhurnal), 2012, 3, pp. 130-137.

13. Karhapolov Yu.V., Lohunova A.O. Analyz tekushcheho sostoianyia protiazhennykh hornykh vyrabotok uholnykh shakht HP Selydovuhol // Visnyk Kryvorizkoho Natsionalnoho Universytetu, 2015, 39, pp. 97-101.

14. Rahimi B., Sharifzadeh M., Feng X.T. Ground behaviour analysis, support system design and construction strategies in deep hard rock mining-Justified in Western Australian's mines // Journal of Rock Mechanics and Geotechnical Engineering, 2020, 12(1), pp. 1-20. https://doi.org/10.1016/j.jrmge.2019.01.006

15. Tereschuk R.N., Grigoriev A.Ye. Examining the state of excavations in the mines of Ltd "Dobropolyeugol" // Zbirnyk Naukovykh Prats DonNTU, 2014, 1, pp. 68-85.

16. Wieja T. Influence of spatial form of underground galleries on geometry and structural design of old mine support constructions // Biuletyn of Polish Society for Geometry and Engineering Graphics, 2017, 30, pp. 63-72.

17. Gasii G.M. Technological and design features of flat- rod elements with usage of composite reinforced concrete // Metallurgical and Mining Industry, 2014, 6(4), pp. 23-25.

18. Storozhenko L.I., Gasii G.M. Experimental research of strain-stress state of ferrocement slabs of composite reinforced concrete structure elements // Metallurgical and Mining Industry, 2014, 6(6), pp. 40-42.

19. Storozhenko L.I., Hasii H.M. The new composite designs for mine tunnel support // Naukovyi Visnyk Natsionalnoho Hirnychoho Universytetu, 2015, (4), pp. 28-34.

20. Gasii G., Hasii O., Zabolotskyi O. Estimate of technical and economic benefits of a new space composite structure // In MATEC Web of Conferences, 2017, 116, 02014. https://doi.org/10.1051/matecconf/201711602014

21. Gasii G., Hasii O., Klimenko V. Testing of the combined structural elements of support of a mine opening // In E3S Web of Conferences, 2020, 168, 00028. EDP Sciences. https://doi.org/10.1051/e3sconf/202016800028

22. Gasii G.M. Production of full-scale experimental modular specimens of the steel and concrete composite cable space frame // Inżynieria Bezpieczeństwa Obiektów Antropogenicznych, 2017, 3, pp. 13-17.

23. DBN V.2.6-98:2009. Konstruktsii budynkiv i sporud. betonni ta zalizobetonni konstruktsii. Osnovni polozhennia (Minrehion Ukrainy, 2011).

24. DBN V.2.6-198:2014. Steel structures. Design code (Minrehion Ukrainy, 2014).

25. DBN V.2.6-160:2010. Konstruktsii budynkiv i sporud. stalezalizobetonni konstruktsii. Osnovni polozhennia (Minrehion Ukrainy, 2010).

26. Shmukler V.S., Krasnov S.N. The use of modular elements in the construction of pedestrian bridges // Naukovi Visti Dalivskoho Universytetu, 2017, 12.

27. Chen W.F., Lui E.M. Handbook of structural engineering. CRC press, 2005.

28. Hasii H.M. Prostorovi Strukturno-Vantovi Stalezalizobetonni Konstruktsii Monohrafiia. Poltava: ASMI, 2018.

29. Hasii H.M. Rekomendatsii Do Proektuvannia Prostorovykh Strukturno-Vantovykh Stalezalizobetonnykh Konstruktsii. Poltava: ASMI, 2018.

\section{СПИСОК ЛІТЕРАТУРИ}

1. Barla G., Barla M. Innovative tunnelling construction methods in squeezing rock // What future for the infrastructure, Pàtron Editore Bologna, 2008, pp. 103-119.

2. Kaiser P.K., Cai M. Design of rock support system under rockburst condition // Journal of Rock Mechanics and Geotechnical Engineering, 2012, 4(3), pp. 215-227. 
3. Uyar G.G., Aksoy C.O. New support suggestions to high swelling clayey rock mass // Journal of Mining Science, 2018, 54(4), pp. 617-627. https://doi.org/10.1134/S1062739118044087

4. Wang M., Zheng D., Niu S., Li W. Large deformation of tunnels in longwall coal mines // Environmental earth sciences, 2019, 78(2), 45. https://doi.org/10.1007/s12665-019-8044-3

5. Bulat A.F. Advanced technologies for tunnel supporting in Ukrainian coal mines // Visnyk of the National Academy of Sciences of Ukraine, 2014, (1), pp. 74-79. https://doi.org/10.15407/visn2014.01.074

6. Elrawy W.R., Abdelhaffez G.S., Saleem H.A. Stability assessment of underground openings using different rock support systems // Rudarsko-geološko-naftni zbornik, 2020, 35(1), pp. 49-64.

7. Gharavi M., Shafiezadeh N. A Comparison of underground opening support design methods in jointed rock mass // International Journal of Engineering, Transactions B: Applications, 2008, 21 (3), pp. 235-248.

8. Storchak G.G, Korol A.Yu, Gapieiev S.M. The issue of increasing the stability of discontinuous workings with metal support under the conditions of irregular loading // Up-to-date resource- and energy-saving technologies in mining industry, 2013, 11(1), pp. 143-152.

9. Khalimendik O.V, Storchak G.G, Khalimendik O.V, Pustoviy V.V. Ways of maintenance prolonged sustainability of long mine workings in conditions unbalanced loads when using metal support spaceframe // Up-to-date resource- and energysaving technologies in mining industry, 2013, 12(2), pp. 157-165.

10. Lu Y., Ke W., Huang X., Xiao M., Huang J., Chen J. Comparative analysis of different construction methods for mine tunnels // In IOP Conference Series: Materials Science and Engineering, 2019, 780(4), 042032. https://doi.org/10.1088/1757$899 X / 780 / 4 / 042032$

11. Stables B., Mirabile B. An improved load measuring device for underground mining standing supports // In Proceedings of the 38th International Conference on Ground Control in Mining, 2019, p. 364. Society for Mining, Metallurgy \& Exploration.

12. Aksenov V.V., Kazantsev A.A., Dortman A.A. Obzor suschestvuyuschih tipov krepi gornyih vyrabotok i analiz ih vozmozhnosti primeneniya $\mathrm{v}$ geovinchesternoy tehnologii // Gornyiy informatsionno-analiticheskiy byulleten (nauchnotehnicheskiy zhurnal), 2012, 3, pp. 130-137.

13. Karhapolov Yu.V., Lohunova A.O. Analyz tekushcheho sostoianyia protiazhennykh hornykh vyrabotok uholnykh shakht HP Selydovuhol // Visnyk Kryvorizkoho Natsionalnoho Universytetu, 2015, 39, pp. 97-101.

14. Rahimi B., Sharifzadeh M., Feng X.T. Ground behaviour analysis, support system design and construction strategies in deep hard rock mining-Justified in Western Australian's mines // Journal of Rock Mechanics and Geotechnical Engineering, 2020, 12(1), pp. 1-20. https://doi.org/10.1016/j.jrmge.2019.01.006

15. Tereschuk R.N., Grigoriev A.Ye. Examining the state of excavations in the mines of Ltd "Dobropolyeugol" // Zbirnyk Naukovykh Prats DonNTU, 2014, 1, pp. 68-85.

16. Wieja T. Influence of spatial form of underground galleries on geometry and structural design of old mine support constructions // Biuletyn of Polish Society for Geometry and Engineering Graphics, 2017, 30, pp. 63-72.

17. Gasii G.M. Technological and design features of flat- rod elements with usage of composite reinforced concrete // Metallurgical and Mining Industry, 2014, 6(4), pp. 23-25.

18. Storozhenko L.I., Gasii G.M. Experimental research of strain-stress state of ferrocement slabs of composite reinforced concrete structure elements // Metallurgical and Mining Industry, 2014, 6(6), pp. 40-42.

19. Storozhenko L.I., Hasii H.M. The new composite designs for mine tunnel support // Naukovyi Visnyk Natsionalnoho Hirnychoho Universytetu, 2015, (4), pp. 28-34.

20. Gasii G., Hasii O., Zabolotskyi O. Estimate of technical and economic benefits of a new space composite structure // In MATEC Web of Conferences, 2017, 116, 02014. https://doi.org/10.1051/matecconf/201711602014

21. Gasii G., Hasii O., Klimenko V. Testing of the combined structural elements of support of a mine opening // In E3S Web of Conferences, 2020, 168, 00028. EDP Sciences. https://doi.org/10.1051/e3sconf/202016800028

22. Gasii G.M. Production of full-scale experimental modular specimens of the steel and concrete composite cable space frame // Inżynieria Bezpieczeństwa Obiektów Antropogenicznych, 2017, 3, pp. 13-17.

23. ДБН В.2.6-98:2009. Конструкції будинків і споруд. Бетонні та залізобетонні конструкції. Основні положення (Мінрегіон України, 2011).

24. ДБН В.2.6-198:2014. Steel structures. Design code (Мінрегіон України, 2014).

25. ДБН В.2.6-160:2010. Конструкції будинків і споруд. Сталезалізобетонні конструкції. Основні положення (Мінрегіон України, 2010).

26. Shmukler V.S., Krasnov S.N. The use of modular elements in the construction of pedestrian bridges // Naukovi Visti Dalivskoho Universytetu, 2017, 12.

27. Chen W.F., Lui E.M. Handbook of structural engineering. CRC press, 2005.

28. Гасій Г.М. Просторові структурно-вантові сталезалізобетонні конструкції: монографія. Полтава: АСМI, 2018.

29. Гасій Г.М. Рекомендації до проектування просторових структурно-вантових сталезалізобетонних конструкцій. Полтава: АCMI, 2018.

Gasii Grygorii - Doctor of Engineering Sciences, Associate Professor, Head of Department of Construction Technology; Sumy National Agrarian University. E-mail: grygorii.gasii@snau.edu.ua, https://orcid.org/0000-00021492-0460.

Hasii Olena - PhD, Associate Professor, Associate Professor of the Department of Finance and Banking; Poltava University of Economics and Trade. E-mail: o.v.hasii@gmail.com, https://orcid.org/0000-0002-5116-0448. 


\title{
ЛАБОРАТОРНІ ВИПРОБОВУВАННЯ КОМБІНОВАНИХ ПОДОВЖЕННИХ СТРУКТУРНИХ ЕЛЕМЕНТІВ ДЛЯ КОНСТРУКЦЙ КРІПЛЕННЯ ГІРНИЧОЇ ВИРОБКИ
}

\author{
${ }^{1}$ Сумський національний аграрний університет, Суми, Україна \\ 2 Полтавський університет економіки і торгівлі, Полтава, Україна
}

Вивчено напружено-деформований стан зразків нової комбінованої конструкції кріплення гірничої виробки під навантаженнями. Експериментальні зразки - модульні елементи раніше розробленої комбінованої конструкції кріплення. Кожен окремий модульний елемент - трикутна призма, що складається із залізобетонної плити та сталевої решітки, виготовленої з трубчастих елементів. Елементи плити та решітки групуються у цілісний елемент під час бетонування плити. Для дослідження зразків застосовується метод експериментального дослідження з використанням тензорезисторів. Випробування зразків проводилися під навантаженням, прикладеного у вигляді металевих вантажів. Навантаження прикладалося таким чином, щоб імітувати умови роботи, враховуючи найбільш несприятливі. Показано особливості конструкції дослідних зразків та випробування. Коротко описуються конструкція кріплення та ї елементів, технологія виробництва, вузли, а також розміри. Представлено методологію випробування зразків, а також аналіз результатів.

Ключові слова: сталезалізобетонні конструкції, комбіновані конструкції, напружено-деформований стан, решітка, гірнича виробка.

Гасій Григорій Михайлович - д.т.н., доцент, завідувач кафедри будівельного виробництва; Сумський національний аграрний університет. E-mail: grygorii.gasii@snau.edu.ua, https:/orcid.org/0000-0002-1492-0460.

Гасій Олена Володимирівна - к.е.н., доцент, доцент кафедри фінансів та банківської справи; Полтавський університет економіки і торгівлі. E-mail: o.v.hasii@gmail.com, https://orcid.org/0000-0002-51160448.

Г. М. Гасий ${ }^{1}$

Е. В. Гасий

\section{ЛАБОРАТОРНЫЕ ИСПЫТАНИЯ КОМБИНИРОВАННЫХ УДЛИНЕННЫХ СТРУКТУРНЫХ ЭЛЕМЕНТОВ ДЛЯ КОНСТРУКЦИЙ КРЕПЛЕНИЯ ГОРНОЙ ВЫРАБОТКИ}

\footnotetext{
${ }^{1}$ Сумской национальный аграрный университет

2 Полтавский университет экономики и торговли
}

Изучено напряженно-деформированное состояние образцов новой комбинированной конструкции крепления горной выработки под нагрузками. Экспериментальные образцы - модульные элементы ранее разработанной комбинированной конструкции крепления. Каждый отдельный модульный элемент треугольная призма, состоящая из железобетонной плиты и стальной решетки, изготовленной из трубчатых элементов. Элементы плиты и решетки группируются в иелостный элемент во время бетонирования плиты. Для исследования образцов применяется метод экспериментального исследования $c$ использованием тензорезисторов. Испытания образцов проводились под нагрузкой, приложенной в виде металлических грузов. Нагрузка прикладывалась таким образом, чтобы имитировать условия работы, учитывая наиболее неблагоприятные. Показаны особенности конструкции опытных образцов и испытания. Кратко описываются конструкция крепления и ее элементов, технология производства, узлы, а также размеры. Представлены методология испытания образцов, а также анализ результатов.

Ключевые слова: сталежелезобетонные конструкции, комбинированные конструкции, напряженнодеформированное состояние, решетка, горная выработка.

Гасий Григорий Михайлович - д.т.н., доцент, заведующий кафедрой строительного производства; Сумской национальный аграрный университет. E-mail: grygorii.gasii@snau.edu.ua, https://orcid.org/0000-0002-14920460.

Гасий Елена Владимировна - к.е.н., доцент, доцент кафедры финансов и банковского дела; Полтавский университет экономики и торговли. E-mail: o.v.hasii@gmail.com, https://orcid.org/0000-0002-5116-0448. 